УДК 631.6:626.86

DOI https://doi.org/10.32848/agrar.innov.2021.5.9

\title{
ДРЕНАЖНИЙ СТІК ЯК ДОДАТКОВЕ ДЖЕРЕЛО ВОДНИХ РЕСУРСІВ НА ІНГУЛЕЦЬКІЙ ЗРОШУВАЛЬНІЙ СИСТЕМІ
}

\author{
КОЗЛЕНКО Є.В. - кандидат сільськогосподарських наук \\ http://orcid.org/0000-0003-3001-8220 \\ Інститут зрошуваного землеробства Національної академії аграрних наук України \\ МОРОЗОВ О.В. - доктор сільськогосподарських наук, професор \\ http://orcid.org/0000-0002-5617-0813 \\ Херсонський державний аграрно-економічний університет \\ МОРОЗОВ В.В. - кандидат сільськогосподарських наук, професор \\ http://orcid.org/0000-0002-2594-883X \\ Херсонський державний аграрно-економічний університет
}

Постановка проблеми. У Південному сухостеповому регіоні України проблема забезпечення водними ресурсами $\epsilon$ актуальною. Запаси водних ресурсів із кожним роком зменшуються, погіршується їхня якість, дорожчає вартість використання води в усіх галузях економіки, у тому числі у сільському господарстві, де вода переважно $€$ джерелом зрошення сільськогосподарських культур. Ці проблеми відносяться і до Інгулецького зрошуваного масиву, який розташований на території Херсонської і Миколаївської областей, є типовим для значної території цих областей, а також подібних умов Одеської, Запорізької, Донецької та Дніпропетровської областей за геологічними, інженерно-геологічними, гідрогеологічними, геоморфологічними, ландшафтними, ґрунтовими, кліматичними, еколого-меліоративними, екологічними, соціальними, сільськогосподарськими та водогосподарськими умовами водокористування.

В умовах наростаючого дефіциту водних ресурсів у сухостеповій зоні, чому сприяє стала тенденція змін клімату в бік його посушливості, важливо комплексне, раціональне використання всіх джерел водних ресурсів, як поверхневих, так і підземних вод. Одним із таких джерел на зрошувальних масивах і на території підтоплених штучно дренованих населених пунктів $€$ дренажний стік, який здебільшого відводиться з підтопленої території і не використовується. Нині за винятком рисових зрошувальних систем в Південному регіоні України відсутні науково-методичні напрацювання і рекомендації з питань можливого використання дренажних вод для зрошення та інших потреб суспільства. В умовах підвищення посушливості клімату відновлюються площі зрошувальних систем, збільшується питоме водопостачання на масиви зрошення, а отже, у природно безстічній слабодренованій зоні буде відновлення і нове будівництво як зрошувальних, так і дренажних систем, як горизонтального, вертикального, так і комбінованого. При цьому слід очікувати зростання дренажного стоку різного гідрохімічного складу і мінералізації, який необхідно відводити та раціонально використовувати.

Дренажний стік - це стік, який збирається і відводиться дренами, колекторами і дренажними системами зі зрошувальних та осушувальних систем. Якщо можливі повна акумуляція дренажного стоку та подальше його використання для зрошення сільськогосподарських культур, то необхідно оцінити наслідки, як це вплине на формування еколого-меліоративного стану зрошуваних та прилеглих до них земель, родючість і продуктивність ґрунтів, а також, який це дасть економічний ефект. Але передусім необхідно одержувати сучасну об'єктивну інфрормацію про формування дренажного стоку на зрошуваному масиві, його кількісні й якісні характеристики.

Дослідження формування якості дренажно-скидних вод Інгулецького зрошуваного масиву та наукове обґрунтування можливості їх повторного використання для зрошення на безстічних і слабодренованих водорозподільних рівнинах Південного регіону України $\epsilon$ актуальним питанням.

Аналіз останніх досліджень і публікацій. Науковотехнічне обґрунтування та практичне використання дренажно-скидних вод на зрошуваних масивах півдня України висвітлено в роботах В.О. Ушкаренка, Б.А. Тупіцина, В.Т.Асатряна,Д.П.Савчука,В.В.Колесникова,В.В.Морозова, В.Г. Корнбергера, Л.М. Грановської, О.В. Морозова, К.В. Дудченко та ін. [6-8; 11; 12]. Ці дослідження були проведені як на звичайних, так і на рисових зрошувальних системах в умовах Північно-Кримського, Краснознам'янського та Інгулецького зрошуваних масивів. Формування якості поливної води Інгулецької зрошувальної системи та спрямованість при цьому ґрунтових процесів досліджувалися Б.А. Тупіциним, О.П. Сафоновою, П.С. Лозовіцьким, В.В. Морозовим, О.В. Морозовим, Є.В. Козленком, Є.В. Волочнюком, В.М. Нежлукченко, І.О. Бідниною та іншими вітчизняними вченими [1-5; 11].

Мета статті. На основі вивчення процесу фрормування кількісних і якісних показників дренажного стоку надати комплексну оцінку можливості використання дренажних вод як додаткового водного ресурсу на безстічних і слабодренованих водорозподільних рівнинах у Південному регіоні України (на прикладі Інгулецької зрошувальної системи).

Матеріали та методика досліджень. У дослідженнях використано матеріали Снігурівської гідрогеолого-меліоративної партії Держводагентства України, Управління каналів Інгулецької зрошувальної системи, Проблемної науково-дослідної лабораторії еколого-мелілоративного моніторингу агроекосистем сухостепової зони імені професора Д.Г. Шапошникова Херсонського ДАУ та матеріали досліджень авторів статті. 
Використані методи досліджень: польовий експеримент на дослідно-виробничій ділянці, лабораторні дослідження хімічного аналізу дренажної і зрошувальної води, системний аналіз і системний підхід, порівняння, моделювання. Оцінювання якості дренажної води виконано за ДСТУ 2730:2015 «Захист довкілля. Якість природної води для зрошення. Агрономічні критерії» (далі - ДСТУ 2730:2015) та Постанови Кабінету Міністрів України від 02.09.2020 № 766 «Про нормативи екологічно безпечного зрошення, осушення, управління поливами та водовідведенням» (далі - Постанова № 766) [9; 10].

Результати досліджень. Основним об'єктом дослідження є дренажна вода з ділянок горизонтального систематичного дренажу, які розташовані на землях ТОВ «Агроторговельна фрірма «Агро-Діло» (колишнє сіль- ськогосподарське підприємство «Баратівське»), тому що у цьому та інших господарствах, які отримують воду з розподільчого каналу Р-1 Інгулецької зрошувальної системи, актуальною проблемою $є$ нестача води у найбільш напружений час поливного періоду (червень-липень). Це відбувається внаслідок того, що пропускна спроможність каналу P-1 не дає змоги забезпечити водою одночасно всіх водокористувачів, ураховуючі те, що в сучасних умовах вони не завжди дотримуються науково обґрунтованих сівозмін та режимів зрошення, під які розрахований проєктний гідромодуль каналу Р-1, що дорівнює 0,33 л/с на 1 га.

Виконано оцінювання якості дренажної води за агрономічними критеріями згідно з ДСТУ 2730:2015 та Постановою № 766 (табл. 1-4).

Таблиця 1 - Оцінювання якості дренажної води Інгулецької зрошувальної системи (ТОВ «АТФ «Агро-Діло») за небезпекою іригаційного засолення ґрунту (у разі використання їі для поливу сільськогосподарських культур)

\begin{tabular}{|c|c|c|c|c|c|c|c|c|}
\hline \multirow[b]{4}{*}{ Роки } & \multicolumn{6}{|c|}{ За ДСТУ 2730:2015 } & \multicolumn{2}{|c|}{ Згідно з Постановою КМУ № 766} \\
\hline & \multicolumn{6}{|c|}{ групи ґрунтів І3С за їх гранулометричним складом у шарі 0-100 см } & \multirow{3}{*}{$\begin{array}{l}\text { концентрація } \\
\text { токсичних іонів } \\
\text { у еквівалентах } \\
\text { хлорид-іонів } \\
\text { в зрошувальній } \\
\text { воді, мекв/дм }\end{array}$} & \multirow[b]{3}{*}{ норматив } \\
\hline & \multicolumn{2}{|c|}{ середньо-суглинковий } & \multicolumn{2}{|c|}{ важко-суглинковий } & \multicolumn{2}{|l|}{ глинистий } & & \\
\hline & $\begin{array}{c}\text { концентрація } \\
\text { токсичних іонів } \\
\text { в еквівалентах } \\
\text { хлорид-іонів, } \\
\text { мекв/дм³ }\end{array}$ & 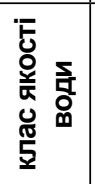 & $\begin{array}{c}\text { концентрація } \\
\text { токсичних іонів } \\
\text { в еквівалентах } \\
\text { хлорид-іонів, } \\
\text { мекв/дм }\end{array}$ & 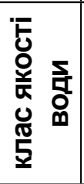 & $\begin{array}{c}\text { концентрація } \\
\text { токсичних іонів } \\
\text { в еквівалентах } \\
\text { хлорид-іонів, } \\
\text { мекв/дм }\end{array}$ & 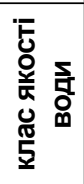 & & \\
\hline 1 & 2 & 3 & 4 & 5 & 6 & 7 & 8 & 9 \\
\hline 2011 & 13,66 & I & 13,66 & I & 13,66 & II & 13,66 & полив безпечний \\
\hline 2012 & 18,95 & II & 18,95 & II & 18,95 & II & 18,95 & полив можливий за \\
\hline 2013 & 19,58 & II & 19,58 & II & 19,58 & II & 19,58 & умови застосування \\
\hline 2014 & 17,65 & I & 17,65 & II & 17,65 & II & 17,65 & $\begin{array}{l}\text { відновлювальних } \\
\text { заходів }\end{array}$ \\
\hline 2015 & 13,12 & $\mathrm{I}$ & 13,12 & $\mathrm{I}$ & 13,12 & II & 13,12 & полив безпечний \\
\hline 2017 & 12,10 & I & 12,10 & I & 12,10 & II & 12,10 & полив безпечний \\
\hline 2018 & 15,05 & I & 15,05 & II & 15,05 & II & 15,05 & полив можливий за \\
\hline 2020 & 15,50 & $\mathrm{I}$ & 15,50 & II & 15,50 & II & 15,50 & умови застосування \\
\hline Середнє & 15,70 & I & 15,70 & II & 15,70 & II & 15,70 & $\begin{array}{l}\text { відновлювальних } \\
\text { заходів }\end{array}$ \\
\hline
\end{tabular}

Таблиця 2 - Оцінка якості дренажної води Інгулецької зрошувальної системи (ТОВ «АТФ «Агро-Діло») за небезпекою підлуження ґрунту (у разі використання її для поливу сільськогосподарських культур)

\begin{tabular}{|c|c|c|c|c|c|c|}
\hline \multirow{3}{*}{ Роки } & \multicolumn{4}{|c|}{ За ДСТУ 2730:2015 } & \multicolumn{2}{|r|}{ Згідно з Постановою КМУ № 766} \\
\hline & \multirow{2}{*}{$\mathrm{pH}$} & $\mathrm{CO}_{3}^{-2}$ & $\mathrm{HCO}_{3}^{-}-$'-Ca $^{2+}$ & \multirow{2}{*}{$\begin{array}{c}\text { Клас } \\
\text { якості води }\end{array}$} & \multirow{2}{*}{$\begin{array}{c}\mathrm{pH} \\
\text { води } \\
\end{array}$} & \multirow{2}{*}{ Норматив } \\
\hline & & & екв/дм ${ }^{3}$ & & & \\
\hline 2011 & 7,65 & - & 3,45 & II & 7,65 & $\begin{array}{l}\text { полив можливий за умови застосування } \\
\text { відновлювальних заходів }\end{array}$ \\
\hline 2012 & 7,15 & - & 4,80 & II & 7,15 & $\begin{array}{l}\text { полив можливий за умови застосування } \\
\text { відновлювальних заходів }\end{array}$ \\
\hline 2013 & 8,06 & - & 5,65 & II & 8,06 & $\begin{array}{l}\text { полив можливий за умови застосування } \\
\text { відновлювальних заходів }\end{array}$ \\
\hline 2014 & 8,11 & - & 5,55 & II & 8,11 & $\begin{array}{l}\text { полив можливий за умови застосування } \\
\text { відновлювальних заходів }\end{array}$ \\
\hline 2015 & 7,84 & - & 5,65 & II & 7,84 & $\begin{array}{l}\text { полив можливий за умови застосування } \\
\text { відновлювальних заходів }\end{array}$ \\
\hline 2017 & 7,72 & - & 4,35 & II & 7,72 & $\begin{array}{l}\text { полив можливий за умови застосування } \\
\text { відновлювальних заходів }\end{array}$ \\
\hline 2018 & 7,53 & - & 5,05 & II & 7,53 & $\begin{array}{l}\text { полив можливий за умови застосування } \\
\text { відновлювальних заходів }\end{array}$ \\
\hline 2020 & 7,85 & - & 5,25 & II & 7,85 & $\begin{array}{l}\text { полив можливий за умови застосування } \\
\text { відновлювальних заходів }\end{array}$ \\
\hline $\begin{array}{c}\text { Середнє за } \\
2011-2020 \text { рр. }\end{array}$ & 7,74 & - & 4,97 & II & 7,74 & $\begin{array}{l}\text { полив можливий за умови застосування } \\
\text { відновлювальних заходів }\end{array}$ \\
\hline
\end{tabular}


Таблиця 3 - Оцінка якості дренажної води Інгулецької зрошувальної системи (ТОВ «АТФ «Агро-Діло») за небезпекою осолонцювання ґрунту (у разі використання їі для поливу сільськогосподарських культур)

\begin{tabular}{|c|c|c|c|c|c|c|c|c|}
\hline \multirow{3}{*}{ Роки } & \multicolumn{6}{|c|}{ За Дсту 2730:2015 } & \multicolumn{2}{|c|}{$\begin{array}{c}\text { Згідно } \\
\text { з Постановою КМУ } \\
\text { № } 766\end{array}$} \\
\hline & \multicolumn{2}{|c|}{$\begin{array}{c}\text { Темно-каштанові } \\
\text { і каштанові суглинкові, } \\
\text { середньо- і високобу- } \\
\text { ферні ґрунти }\end{array}$} & \multicolumn{2}{|c|}{$\begin{array}{l}\text { Черноземні ґрунти } \\
\text { суглинкові середньо- } \\
\text { і високобуферні }\end{array}$} & \multicolumn{2}{|c|}{$\begin{array}{l}\text { Черноземні ґрунти } \\
\text { глинисті середньо- } \\
\text { і високобуферні }\end{array}$} & \multirow{2}{*}{ 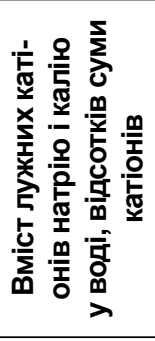 } & \multirow[b]{2}{*}{ Норматив } \\
\hline & $\begin{array}{c}\text { Співвідношення } \\
\text { суми лужних } \\
\text { катіонів натрію } \\
\text { і калію до суми } \\
\text { всіх катіонів, \% }\end{array}$ & $\begin{array}{c}\text { Клас } \\
\text { якості } \\
\text { води }\end{array}$ & $\begin{array}{c}\text { Співвідношення } \\
\text { суми лужних } \\
\text { катіонів натрію } \\
\text { і калію до суми } \\
\text { всіх катіонів, \% }\end{array}$ & $\begin{array}{c}\text { Клас } \\
\text { якості } \\
\text { води }\end{array}$ & $\begin{array}{c}\text { Співвідношення } \\
\text { суми лужних } \\
\text { катіонів натрію } \\
\text { і калію до суми } \\
\text { всіх катіонів, \% }\end{array}$ & $\begin{array}{c}\text { Клас } \\
\text { якості } \\
\text { води }\end{array}$ & & \\
\hline 2011 & 46,48 & I & 46,48 & II & 46,48 & III & 46,48 & $\begin{array}{l}\text { полив } \\
\text { заборонено }\end{array}$ \\
\hline 2012 & 45,32 & I & 45,32 & II & 45,32 & III & 45,32 & \begin{tabular}{|l|} 
полив \\
заборонено
\end{tabular} \\
\hline 2013 & 42,73 & $\mathrm{I}$ & 42,73 & I & 42,73 & III & 42,73 & \begin{tabular}{|l} 
полив \\
заборонено
\end{tabular} \\
\hline 2014 & 41,82 & I & 41,82 & I & 41,82 & III & 41,82 & \begin{tabular}{|l} 
полив \\
заборонено
\end{tabular} \\
\hline 2015 & 41,93 & I & 41,93 & I & 41,93 & III & 41,93 & \begin{tabular}{|l|} 
полив \\
заборонено
\end{tabular} \\
\hline 2017 & 39,98 & 1 & 39,98 & I & 39,98 & II & 39,98 & \begin{tabular}{|l|} 
полив \\
можливий \\
за умови \\
засто- \\
сування \\
відновлю- \\
вальних \\
заходів \\
\end{tabular} \\
\hline 2018 & 46,70 & 1 & 46,70 & II & 46,70 & III & 46,70 & $\begin{array}{l}\text { полив } \\
\text { заборонено }\end{array}$ \\
\hline 2020 & 42,73 & I & 42,73 & I & 42,73 & III & 42,73 & $\begin{array}{l}\text { полив } \\
\text { заборонено }\end{array}$ \\
\hline $\begin{array}{c}\text { Середнє за } \\
2011-2020 \text { рр. }\end{array}$ & 43,57 & $I$ & 43,57 & I & 43,57 & III & 43,57 & \begin{tabular}{|l} 
полив \\
заборонено
\end{tabular} \\
\hline
\end{tabular}

Таблиця 4 - Оцінка якості дренажної води Інгулецької зрошувальної системи (ТОВ «АТФ «Агро-Діло») за небезпекою їі токсичного впливу на рослини за поливів дощуванням (у разі використання їі для поливу сільськогосподарських культур)

\begin{tabular}{|c|c|c|c|c|c|c|}
\hline \multirow{3}{*}{ Роки } & \multicolumn{5}{|c|}{ 3а ДСТУ 2730:2015 } & \multirow{3}{*}{$\begin{array}{c}\text { 3гідно з Постановою КМУ № } 766 \\
\text { Норматив }\end{array}$} \\
\hline & \multirow[t]{2}{*}{ pH } & $\mathrm{CO}_{3}^{-2}$ & $\mathrm{Cl}^{-}$ & \multirow{2}{*}{$\begin{array}{c}\text { Токсичні } \\
\text { іони, } \\
\text { еквіва- } \\
\text { лентів Сl- }\end{array}$} & \multirow[t]{2}{*}{$\begin{array}{c}\text { Клас } \\
\text { якості } \\
\text { води }\end{array}$} & \\
\hline & & \multicolumn{2}{|c|}{ мекв/дм ${ }^{3}$} & & & \\
\hline 2011 & 7,65 & - & 10,80 & 13,66 & II & полив можливий за умови застосування відновлювальних заходів \\
\hline 2012 & 7,15 & - & 11,99 & 18,95 & II & полив можливий за умови застосування відновлювальних заходів \\
\hline 2013 & 8,06 & - & 14,40 & 19,58 & II & полив можливий за умови застосування відновлювальних заходів \\
\hline 2014 & 8,11 & - & 12,80 & 17,65 & II & полив можливий за умови застосування відновлювальних заходів \\
\hline 2015 & 7,84 & - & 10,15 & 13,12 & II & полив можливий за умови застосування відновлювальних заходів \\
\hline 2017 & 7,72 & - & 9,60 & 12,10 & II & полив можливий за умови застосування відновлювальних заходів \\
\hline 2018 & 7,53 & - & 11,60 & 15,05 & II & полив можливий за умови застосування відновлювальних заходів \\
\hline 2020 & 7,85 & - & 11,71 & 15,50 & II & полив можливий за умови застосування відновлювальних заходів \\
\hline $\begin{array}{c}\text { Середнє за } \\
2011-2020 \text { рр. }\end{array}$ & 7,74 & - & 11,63 & 15,70 & II & полив можливий за умови застосування відновлювальних заходів \\
\hline
\end{tabular}


На безстічних і слабодренованих водорозподільних рівнинах Південного регіону України, в умовах яких розташована Інгулецька зрошувальна система (IЗС), для боротьби з підтопленням зрошуваних та прилеглих до них земель і забезпечення сприятливого водно-сольового режиму зрошуваних ґрунтів необхідне фрункціонування закритого горизонтального дренажу.

Дослідженнями Б.А. Тупіцина, В.Т. Асатряна, В.В. Морозова [11] встановлено, що для умов Інгулецької зрошувальної системи оптимальними параметрами горизонтального дренажу є: міждренна відстань 200-250 м, глибина дрен - 2,8-3,2 м, діаметр дрен 0,10-0,15 м, матеріал дрен - полівінілхлоридні труби (ПВХ). Горизонтальний дренаж із відповідними параметрами забезпечує зниження глибини слабо- і середньомінералізованих ґрунтових вод $\left(\mathrm{H}_{\text {гв}}\right)$ не менше 1,2-1,5 м навесні за середнього модуля дренажного стоку $q=0,04$ л/с 31 га; влітку $\mathrm{H}_{\mathrm{rв}}=1,5-1,8$ м за $q=0,03-0,04$ л/с з 1 га; восени $\mathrm{H}_{\text {гв }} \geq 1,8-2,8$ м за $q=0,02$ л/с з 1 га; взимку $\mathrm{H}_{\mathrm{rв}}=1,3-1,5$ м за $q=0,03$ л/с з 1 га [11]. Робота горизонтального дренажу в умовах нормованого зрошення забезпечує безпеку вторинного засолення ґрунтів, поліпшення еколого-меліоративного стану зрошуваних земель та приріст урожаю сільськогосподарських культур на 20-25\%. Результати досліджень [11] показали, що на Інгулецькій зрошувальній системі за допомогою закритого горизонтального дренажу можливо здійснювати регулювання рівнів слабо- і середньомінералізованих (1,0-3,0 г/дм³ $)$ ґрунтових вод шляхом закриття окремих дрен або відключенням дренажних насосних станцій (ДНС). Величина інфільтраційного живлення ґрунтових вод від поливів та атмосферних опадів досягає 25-35\% від водонадходження й є основним джерелом поповнення ґрунтових вод.

Упровадження на Інгулецькій зрошувальній системі керованого за допомогою горизонтального дренажу і зрошення іригаційно-кліматичного напівгідроморфного та гідроморфного режимів ґрунтових вод та відповідного еколого-меліоративного режиму забезпечує необхідну стабільність ґрунтотворного процесу, а також режим водозбереження, зменшення зрошувальних норм на 600-800 м³/га без зниження врожайності сільськогосподарських культур [11]. Комплексна оцінка придатності дренажних вод для зрошення приведена в табл. 1-4.

Оцінювання якості дренажної води Інгулецької зрошувальної системи (за період 2011-2020рр.) за небезпекою вторинного засолення ґрунту (за умови використання даної води для зрошення) показало, що в середньому поливи цією водою можливі за умови застосування відновлювальних заходів (табл. 1). До відновлювальних профілактичних агромеліоративних заходів відносяться: поліпшення якості води і корегування режимів зрошення, внесення кальцієвмісних меліорантів (гіпс, фосфогіпс, дроблений вапняк, дефекат) та нормативних доз органічних добрив, уведення у сівозміни багаторічних трав та сидератів.

Оцінка якості дренажної води I3С за небезпекою підлуження ґрунту в разі використання ії̈ для поливів (табл. 2) показала також, що в усі роки спостережень (2011-2020 рр.) вода відноситься до II класу якості і полив можливий за умови застосування відновлювальних агромеліоративних заходів.

Оцінка якості дренажної води I3C за небезпекою осолонцювання ґрунту в разі її використання для поливу сільськогосподарських культур (табл. 3) показала, що для темно-каштанових і каштанових суглинкових, середньо- і високобуферних ґрунтів (що переважно відноситься до ґрунтів ІЗС у Херсонській області) вода має I клас якості; для чорноземів південних, суглинкових середньо- і високобуферних - до I, II класів якості. Тобто полив допускається за впровадження всього комплексу відновлювальних агромеліоративних заходів. Згідно з Постановою КМУ від 02.09.2020 № 766 [10], поливи такою водою забороняються, тому що є загроза небезпеки осолонцювання чорноземних глинистих, середньоі високобуферних ґрунтів. Для чорноземів південних, глиністих середньо- і високобуферних дренажна вода стабільно характеризується III класом якості за чинним ДСТУ 2730:2015 (полив заборонено). У цьому разі за дефріциту зрошувальної води слід розглядати можливість використання дренажних вод для поливів у змішуванні їх зі зрошувальною водою і постійним проведенням агромеліоративних відновлювальних заходів та за використання цієї води у цілях обводнення територій (створення і промислове використання ставків в існуючій яружно-балочній мережі Інгулецького масиву).

Оцінка якості дренажної води Інгулецької зрошувальної системи за небезпекою токсичного впливу її на рослини за поливів дощуванням показала (табл. 4), що ця вода стабільно характеризується II класом якості (як переважно і зрошувальна вода з магістрального каналу І3С) і, згідно з Постановою КМУ від 02.09.2020 № 766, полив можливий за умови застосування комплексу відновлювальних агромеліоративних заходів.

Динаміка мінералізації та вмісту аніонів хлору в дренажній води в період 2005-2020 рр. (рис. 1) показує, що в середньому мінералізація знаходиться у межах 2,1-2,2 г/дм³ ${ }^{3}$ уміст хлорід-іону - 10,0-12,0 мг-еквг/дм³

Для виявлення закономірностей формування хімічного складу дренажно-скидних вод було проведено кореляційний і регресійний аналіз взаємозалежності мінералізації дренажно-скидних вод та змісту іонів (обсяг вибірки - $п=15$ ) (рис. 2). Аналізом установлено, що сильний функціональний зв'язок відзначається між ступенем мінералізації дренажних вод та сульфат іонами $(r=0,98)$, іонами натрію $(r=0,96)$, іонами магнію ( $r=0,93)$; середній - між ступенем мінералізації дренажних вод та іонами хлору $(r=0,60)$, кальцію $(r=0,60)$; слабкий зв'язок - між ступенем мінералізації дренажних вод і гідрокарбонат іону $(\ulcorner=0,44)$. Дослідженнями визначено, що в умовах Інгулецького зрошуваного масиву збільшення мінералізації дренажних вод відбувається переважно за рахунок сульфат-іонів, іонів натрію і магнію, значно в меншому ступені це стосується збільшення змісту хлорид-іонів, гідрокарбонат іонів та іонів кальцію (рис. 2).

Виявлені взаємозалежності аніонно-катіонного складу дренажних вод та їх мінералізації необхідні для: перевірки достовірності хімічних аналізів води, а також моделювання і прогнозування хімічного складу дренаж- 


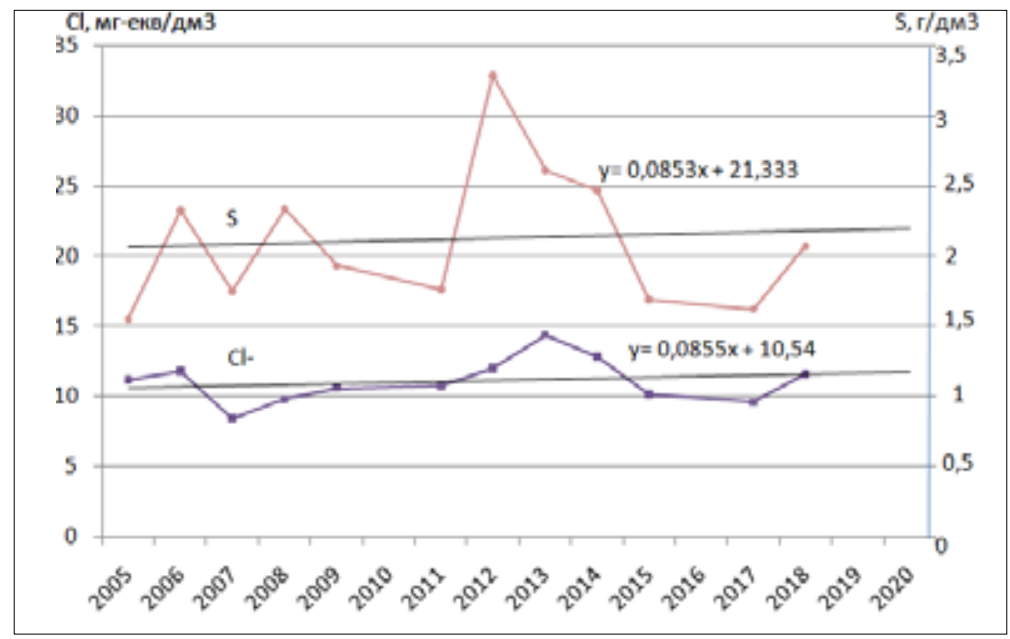

Рис. 1. Динаміка мінералізації та вмісту аніону хлору у дренажній воді в поливний період за 2005-2020 рр. (ТОВ «АТФ «Агро-Діло», Снігурівський район, Миколаївська область)
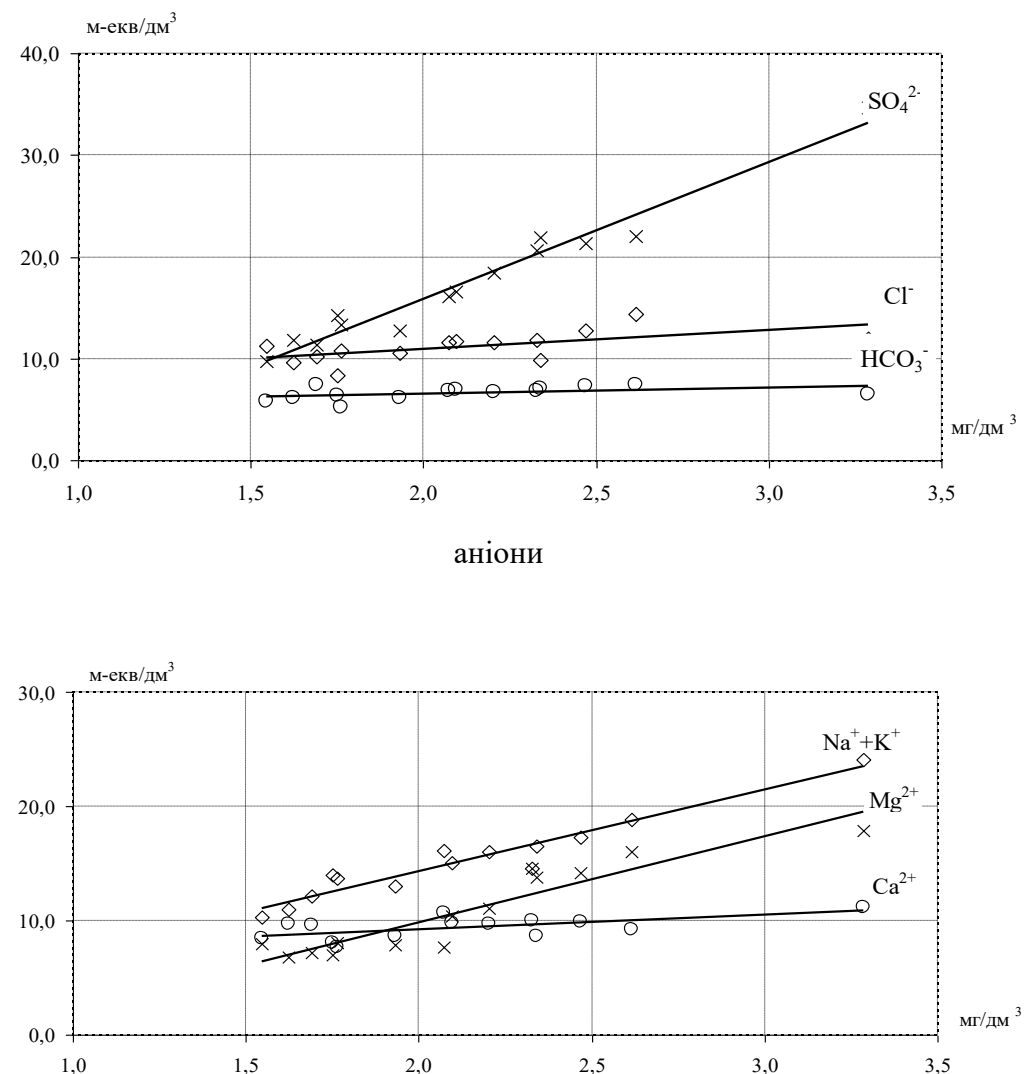

катіони

\begin{tabular}{|c|c|c|}
\hline Рівняння регресії & Коефіцієнт детермінації & Коефіцієнт кореляції \\
\hline $\mathrm{HCO}_{3}-=0,6012 \mathrm{x}+5,3504$ & $\mathrm{R}^{2}=0,1964$ & $r=0,44$ \\
\hline $\mathrm{Cl}^{-}=1,8764 \mathrm{x}+7,1946$ & $\mathrm{R}^{2}=0,3587$ & $r=0,60$ \\
\hline $\mathrm{SO}_{4}^{2-}=13,45 \mathrm{x}-11,057$ & $\mathrm{R}^{2}=0,9622$ & $r=0,98$ \\
\hline $\mathrm{Na}^{+} \mathrm{K}^{+}=7,1663 \mathrm{x}-0,0222$ & $\mathrm{R}^{2}=0,9276$ & $r=0,96$ \\
\hline $\mathrm{Ca}^{2+}=1,258 \mathrm{x}+6,7106$ & $\mathrm{R}^{2}=0,3539$ & $r=0,93$ \\
\hline $\mathrm{Mg}^{2+}=7,5223 \mathrm{x}-5,2144$ & $\mathrm{R}^{2}=0,8628$ & \\
\hline
\end{tabular}

Рис. 2. Взаємозалежність аніонно-катіонного складу дренажних вод та їх мінералізації (ТОВ «АТФ «Агро-Діло» Снігурівський район, Миколаївська область, Інгулецький зрошуваний масив) 
них вод, визначення напряму метаморфізму хімічного складу дренажних і ґрунтових вод у процесі функціонування багаторічного зрошення і дренажу в проєктному режимі.

Дренажна вода для поливу сільськогосподарських культур може забиратися зі збірного дренажного колодязя або відкритого дренажного колектора за допомогою пересувної насосної станції з подальшою подачею води до систем зрошення дощуванням, способами поверхневого поливу та краплинного зрошення.

Важливим показником під час комплексної оцінки дренажних вод як додаткового джерела водних ресурсів $€$ кількісні, об'ємні показники дренажного стоку. Дослідженнями встановлено, що за середнього значення розрахункового модулю дренажного стоку 0,025 л/с 31 га і нормативній середньозваженій зрошувальній нормі 3000 м³/га 31 га формується в середньому до $700 \mathrm{~m}^{3}$ дренажної води на рік, або до 350-400 м³ у вегетаційний період, чим може бути забезпечений один полив сільськогосподарських культур.

Із площі 1000 га горизонтального дренажу за проектного режиму його функціонування об'єм дренажного стоку досягає 350-400 тис м³ у вегетаційний період, або 700-800 тис м³ на рік. Ці значні обсяги показують, що в умовах наростаючого дефіциту води дренажний стік можливо розглядати як додаткове джерело водних ресурсів на зрошуваних системах. При цьому необхідною умовою $є$ постійний моніторинг дренажного стоку та хімічного складу дренажних вод.

Перспективою подальших досліджень із даної теми $€$ розроблення концепції, принципів, способів і технологій використання дренажних вод на природно слабодренованих і безстічних водорозподільних зрошуваних масивах у Південному регіоні України.

Висновки. В умовах багаторічного зрошення каштанових, темно-каштанових ґрунтів та чорноземів південних водою I і II класів якості на безстічних і слабодренованих водорозподільних масивах Південного регіону України можливо розглядати дренажні води систем горизонтального систематичного дренажу як додаткове джерело водних ресурсів, що в умовах десріциту води за відповідного їх акумулювання може забезпечувати до

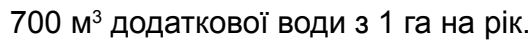

Якість дренажної води є стабільною в багаторічному розрізі. Комплексна оцінка іригаційних показників дренажної води Інгулецького зрошуваного масиву, який $є$ типовим для більшості зрошувальних систем Південного регіону України, показує, що за небезпекою вторинного засолення, підлуження ґрунту, токсичного впливу на рослини поливи дренажною водою $€$ можливими за умови постійного застосування комплексу профілактичних ландшафтно-агромеліоративних заходів. За поливів дренажною водою чорноземів південних глинистих середньо- і високобуферних, згідно 3 нормативами Постанови Кабінету Міністрів України № 766 від 02.09.2020, є небезпека осолонцювання цих ґрунтів, тому поливи можливо проводити за змішування дренажної та зрошувальної води з обов'язковим комплексом агромеліоративних заходів.
Мінералізація дренажних вод знаходиться в середньому у межах 2,1-2,2 г/дм³. Дослідженнями визначено, що в умовах Інгулецького зрошуваного масиву збільшення мінералізації дренажних вод відбувається переважно за рахунок сульфат-іонів, іонів натрію і магнію, значно в меншому ступені це стосується збільшення змісту хлорид-іонів, гідрокарбонат іонів та іонів кальцію.

Актуальним напрямом подальших досліджень у розвитку даної теми $є$ розроблення концепції, принципів, способів і технологій використання дренажних вод для зрошення сільськогосподарських культур та обводнення території, враховуючі ландшафтні, гідрогеолого-меліоративні, кліматичні, водогосподарські та сільськогосподарські умови кожного безстічного і слабо дренованого масиву. Обов'язковим $є$ моніторинг динаміки дренажного стоку і хімічного складу дренажних вод у системі еколого-агромеліоративного моніторингу зрошуваних земель. Необхідно постійне фрормування бази даних і бази знань «Дренажні води» під час розроблення й упровадження експертних систем еколого-агромеліоративного моніторингу зрошуваних земель.

\section{СПИСОК ВИКОРИСТАНОÏ ЛІТЕРАТУРИ:}

1. Інгулецька зрошувальна система: стан, проблеми та перспективи розвитку : монографія / Є.В. Козленко та ін. ; за ред. О.В. Морозова. Херсон : Айлант, 2020. $204 \mathrm{c}$.

2. Оцінкаякостізрошувальноїводивсистеміеколого-меліоративного моніторингу / О.В. Морозов та ін. Водні біоресурси та аквакультура. Сільськогосподарські науки. 2020. № 2. С. 192-209.

3. Параметри змін фрізико - хімічних властивостей темно-каштанового зрошуваного ґрунту за різних меліоративних навантажень / П.В. Писаренко та ін. Зрошуване землеробство. 2018. № 69. С. 64-69.

4. Морозов В.В., Козленко Є.В., Морозов О.В. Шляхи покращення якості поливної води і підвищення родючості ґрунтів Інгулецької зрошувальної системи. Зрошуване землеробство. 2011. № 55. С. 30-38.

5. Обґрунтування критеріїв якості поливної води для Ґрунтів Інгулецького зрошуваного масиву / В.В. Морозов та ін. Таврійський науковий вісник. 2018. № 99. С. 88-93.

6. Закрытая чековая рисовая оросительная система с оборотным циклом водопользования / В.В. Морозов и др. Водосбережение как средство выживания человечества в условиях нарастания водного кризисна : сборник научных трудов Сети водохозяйственных организаций Восточной Европы, Кавказа, Центральной Азии. Вып. 7. Ташкент : НИЦ МКВК, 2015. C. 44-50.

7. Регульоване використання дренажно-скидних вод рисових зрошувальних систем в умовах Краснознам'янського масиву / В.В. Морозов та ін. Природа для води : матеріали міжнар. наук.практ. конф., М. Київ, 22 березня 2018 р. Київ, 2018. C. 177-178.

8. Рисові зрошувальні системи: використання дренажно-скидних вод : монографрія / В.В. Дудченкота ін. Херсон : Грінь Д.С., 2016. 212 с.

9. ДСТУ 2730:2015. Захист довкілля. Якість природної води для зрошення. Агрономічні критерії. Вид. офіц. Київ : Мінекономрозвитку України, 2015. 9 с. 
10. Про нормативи екологічно безпечного зрошення, осушення, управління поливами та водовідведенням : Постанова Кабінету Міністрів України від 02.09.2020 № 766. Офріційний вісник України. 2020. № 73. C. 27-31.

11. Землі Інгулецької зрошувальної системи: стан та ефективне використання : монографрія / за ред. В.О. Ушкаренка, Р.А. Вожегової. Київ : Аграрна наука, 2010. 352 с.

12. Эфрфективное использование засоленных земель Степного Крыма : монография / В.А. Ушкаренко и др. Херсон : Айлант, 2010. 188 с.

\section{References:}

1. Kozlenko, Ye.V., Morozov, O.V., \& Morozov, V.V. (2020). Inhuletska zroshuvalna systema: stan, problemy ta perspektyvy rozvytku: monohrafiia [Ingulets irrigation system: state, problems and prospects of development: monograph]. Kherson: Ailant [in Ukrainian].

2. Morozov, O.V., Morozov, V.V., Kozlenko, Ye.V., \& Bidnyna, I.O. (2020). Otsinka yakosti zroshuvalnoi vody $v$ systemi ekoloho - melioratyvnoho monitorynhu [Assessment of irrigation water quality in the system of ecological and reclamation monitoring]. Vodnibioresursy ta akvakultura: silskohospodarski nauky - Aquatic bioresources and aquaculture: agricultural sciences, 2, 192-209 [in Ukrainian].

3. Pysarenko, P.V., Kozyriev, V.V., Bidnyna, I.O., Shkoda, O.A., \& Morozov, O.V. (2018). Parametry zmin fizyko-khimichnykh vlastyvostei temno-kashtanovoho zroshuvanoho gruntu za riznykh melioratyvnykh navantazhen [Parameters of changes in physical and chemical properties of dark chestnut irrigated soil at different reclamation loads]. Zroshuvane zemlerobstvo Irrigated agriculture, 69, 64-69 [in Ukrainian].

4. Morozov, V.V., Kozlenko, Ye.V., \& Morozov, O.V. (2011). Shliakhy pokrashchennia yakosti polyvno vody i pidvyshchennia rodiuchosti gruntiv Inhuletskoi zroshuvalnoi systemy [Ways to improve the quality of irrigation water and increase soil fertility of the Ingulets irrigation system]. Zroshuvane zemlerobstvo - Irrigated agriculture, 55, 30-38 [in Ukrainian].

5. Morozov, V.V., Morozov, O.V., Chenina, N.O., \& Kozlenko, Ye.V. (2018). Obgruntuvannia kryteriiv yakosti polyvnoi vody dlia hruntiv Inhuletskoho zroshuvanoho masyvu [Substantiation of irrigation water quality criteria for soils of Ingulets irrigated massif]. Tavriyskyy naukovyy visnyk - Taurian Scientific Bulletin, 99, 88-93 [in Ukrainian].

6. Morozov, V.V., Granovskaya, L.M., Kornberger, V.G., Morozov, O.V., Poluhov, A.Ya., \& Dudchenko, K.V. (2015). Zakryitaya chekovaya risovaya orositelnaya sistema s oborotnyim tsiklom vodopolzovaniya [Closed check rice irrigation system with a reverse cycle of water use] Vodosberezhenie kak sredstvo vyizhivaniya chelovechestva v usloviyah narastaniya vodnogo krizisa: sbornik nauchnyih trudov Seti vodohozyaystvennyih organizatsiy Vostochnoy Evropyi, Kavkaza, Tsentralnoy Azii - Water conservation as a means of human survival in the face of the growing water crisis: collection of scientific papers of the Network of water management organizations in Eastern Europe, the Caucasus, Central Asia, 7, 44-50 [in Russian].

7. Morozov, O.V., Morozov, V.V., Dudchenko, K.V., \& Kornberher, V.H. (2018). Rehulovane vykorystannia drenazhno - skydnykh vod rysovykh zroshuvalnykh system $v$ umovakh Krasnoznamianskoho masyvu [Regulated use of drainage and wastewater of rice irrigation systems in the Krasnoznamensky massif]. Materialy mizhn. nauk. - prakt. konf. «Pryroda dlia vody», Kyiv, 177-178 [in Ukrainian].

8. Dudchenko, V.V., Kornberher, V.H., Morozov, V.V., Morozov, O.V., \& Dudchenko, K.V. (2016). Rysovi zroshuvalni systemy: vykorystannia drenazhno skydnykh vod: monohrafiia [Rice irrigation systems: the use of drainage and wastewater: monograph]. Kherson: FOP Hrin D.S. [in Ukrainian].

9. DSTU 2730:2015. Zakhyst dovkillia. Yakist pryrodnoi vody dlia zroshennia. Ahronomichni kryterii [SSU 2730:2015. Environmental Protection. Quality of natural water for irrigation. Agronomic criteria]. Kyiv : Minekonomrozvytku Ukrainy [in Ukrainian].

10. Pro normatyvy ekolohichno bezpechnoho zroshennia, osushennia, upravlinnia polyvamy ta vodovidvedenniam [About norms of ecologically safe irrigation, drainage, management of irrigations and drainage]. Postanova Kabinetu Ministriv Ukrainy vid 02.09.2020 № 766. Ofitsiinyi visnyk Ukrainy. [in Ukrainian].

11. Ushkarenko, V.O., \& Vozhehova, R.A. (Eds). (2010) Zemli Inhuletskoi zroshuvalnoi systemy: stan ta efektyvne vykorystannia: monohrafiia [Lands of Ingulets irrigation system: condition and effective use: monograph]. Kyiv : Ahrarna nauka. [in Ukrainian].

12. Ushkarenko, V.A., Kolesnikov, V.V., \& Morozov, V.V. i dr. (2010). Effektivnoe ispolzovanie zasolennyih zemel Stepnogo Kryima: monografiya [Effective use of saline lands of the Steppe Crimea: monograph]. Kherson : Ailant [in Russian].

Козленко Є.В., Морозов О.В., Морозов В.В. Дренажний стік як додаткове джерело водних ресурсів на Інгулецькій зрошувальній системі

У Південному сухостеповому регіоні України проблема забезпечення водними ресурсами $є$ актуальною. Запаси водних ресурсів із кожним роком зменшуються, погіршується їхня якість, дорожчає вартість використання води в усіх галузях економіки, у тому числі у сільському господарстві, де вода переважно $є$ джерелом зрошення сільськогосподарських культур. Ці проблеми відносяться і до Інгулецького зрошуваного масиву (I33), який розташований на території Херсонської і Миколаївської областей, є типовим для значної території цих областей, а також подібних умов Одеської, Запорізької, Донецької та Дніпропетровської областей за геологічними, інженерно-геологічними, гідрогеологічними, геоморфологічними, ландшафтними, ґрунтовими, кліматичними, еколого-меліоративними, екологічними, соціальними, сільськогосподарськими та водогосподарськими умовами водокористування.

В умовах наростаючого дефріциту водних ресурсів у сухостеповій зоні, чому сприяє стала тенденція змін клімату в бік його посушливості, актуальним $€$ комплексне і раціональне використання всіх джерел водних ресурсів, як поверхневих, так і підземних вод. Одним із таких джерел на зрошуваних масивах і на території підтоплених штучно дренованих населених пунктів $€$ дренажний стік, який здебільшого відводиться з підтопленої території і не використовується. В умовах багаторічного зрошення каштанових, темно-каштанових ґрунтів та чорноземів південних водою I і ІІ класів якості на 
безстічних і слабодренованих водороздільних масивах Південного регіону України дренажні води систем горизонтального систематичного дренажу можливо розглядати як потенціальне додаткове джерело водних ресурсів, що в умовах дефіциту води при відповідному їх акумулюванні може забезпечувати до 700 м³ дренажної води з 1 га на рік.

Комплексна оцінка іригаційних показників дренажної води Інгулецького зрошуваного масиву, який $є$ типовим для більшості зрошувальних систем Південного регіону України, показує, що за небезпекою вторинного засолення, підлуження ґрунту, токсичного впливу на рослини поливи дренажною водою є можливими за умови постійного застосування комплексу профілактичних ландшафтно-агромеліоративних заходів. За поливів дренажною водою чорноземів південних глинистих середньо- і високобуферних, згідно з нормативами Постанови Кабінету Міністрів України № 766 від 02.09.2020, є небезпека осолонцювання цих ґрунтів, тому поливи можливо проводити за змішування дренажної та зрошувальної води з обов'язковим проведенням комплексу агромеліоративних заходів.

У середньому мінералізація дренажно-скидних вод знаходиться у межах 2,1-2,2 г/дм³ ${ }^{3}$. Дослідженнями визначено, що в умовах Інгулецького зрошуваного масиву збільшення мінералізації дренажно-скидних вод відбувається переважно за рахунок сульфат-іонів, іонів натрію і магнію, значно в меншому ступені це стосується збільшення вмісту хлорид-іонів, гідрокарбонат-іонів та іонів кальцію.

Ключові слова: зрошення, горизонтальний дренаж, дренажний стік, якість дренажних вод, комплексна іригаційна оцінка.

Kozlenko Y.V., Morozov O.V., Morozov V.V. Drainage runoff as an additional source of water resources on the Ingulets irrigation system

In the Pivdenny dry steppe region of Ukraine, the problem of water supply is urgent. The reserves of water resources with skin rock change, lose their quality, costly vikorystannya water in all galuzyah of the economy, including in the Silskoy government, de water, in the main culture, the dreamer of the grown-up people. These problems are related to the Inguletsky Zroshuvany Array, which are rooted in the territory of the Kherson and Mykolaiv regions, significant typical for the significant territory of the civilian regions, as well as the geological minds of Odessa, Zaporozhian geomorphological, landscape, earthy, climatic, ecologicalmeliorative, ecological, social, agricultural and water-based water-borne minds.

In the minds of the growing shortage of water resources in the dry steppe zone, which has become a tendency to change the climate in a low degree of dryness, it is relevant for a complex and rational approach to all water resources, such as surface water. One of these dzherel on the growing massifs and on the territory of populated piece-drained settlements is a drainage stick, which in most cases is introduced from the flooded territory and does not become victorious. In the minds of the growing shortage of water resources in the dry steppe zone, which has become a tendency to change the climate in a low degree of dryness, it is relevant for a complex and rational approach to all water resources, such as surface water. One of these dzherel on the growing massifs and on the territory of populated piece-drained settlements is a drainage stick, which in most cases is introduced from the flooded territory and does not become victorious.

Comprehensive assessment of irrigation indicators of drainage water of Ingulets irrigated massif, which is typical for most irrigation systems of the Southern region of Ukraine, shows that the danger of secondary salinization, alkalinization of the soil, toxic effects on plants irrigation with drainage water is possible with constant use of preventive landscapes. measures. When irrigating drainage water of chernozems of southern clay medium and high-buffer, according to the regulations of the Resolution of the Cabinet of Ministers of Ukraine № 766 of 02.09.2020 there is a danger of salinization of these soils, so irrigation can be carried out by mixing drainage and irrigation water measures.

On average, the mineralization of drainage and wastewater is in the range of $2.1-2.2 \mathrm{~g} / \mathrm{dm}^{3}$. Studies have shown that in the conditions of the Ingulets irrigated massif the increase of mineralization of drainage and wastewater occurs mainly due to sulfate ions, sodium and magnesium ions, to a much lesser extent this increases the content of chloride ions, bicarbonate ions and calcium ions.

Key words: drainage, horizontal drainage, drainage stick, quality of drainage water, complex irrigation assessment. 